\title{
Parameter optimization of an inductively coupled plasma mass spectrometer for measuring arsenic and selenium
}

\author{
Dávid Andrási - Anita Puskás-Preszner - Zsuzsa Tarján - Béla Kovács - Zoltán Győri \\ Institute of Food Science, Quality Assurance and Microbiology, Faculty of Agricultural and Food Sciences and Environmental \\ Management, University of Debrecen \\ andrasidavid@freemail.hu
}

Keywords: arsenic, selenium, ICP-MS

\section{SUMMARY}

In the last decades, an increased interest has evolved in arsenic and selenium. The aim is to understand the environmental, agricultural and biological roles of these elements. In the case of arsenic, the major reasons are the relatively high concentration of arsenic in marine biota $\left(\mathrm{mg} \mathrm{kg}^{-1}\right)$ and the arsenic contaminated drinking water bases of some Asian countries, as well as Hungary. The toxicity of higher level selenium content is also known; nevertheless, selenium is essential for several biological functions. Considering its essentialness, in our country, the insufficient selenium intake rate causes a lack of selenium. Measuring the concentrations of these elements provides crucial, but unsatisfactory information, as the speciation, i.e. the form of an element presented in a sample is also required.

In both cases, the most suitable method to determine concentration is inductively coupled plasma mass spectrometry (ICP-MS). Our objective was to optimize the variable parameters of the ICP-MS to attain the lowest (the best) detection limit. For this purpose, we investigated the effect of parameter change on net signal intensity and relative signal intensity. With the optimized parameter settings, the

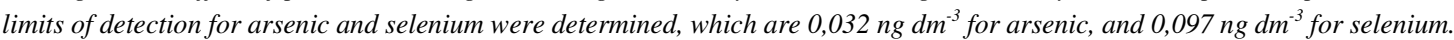

\section{INTRODUCTION}

Recently improved detection limits can be achieved by the evolution of element-specific analytical instruments, through which new horizons of research have been opened, especially in the fields of trace and ultra trace elements, such as arsenic and selenium.

Compared to other element-specific methods, inductively coupled mass spectrometry has the best detection limits for most of elements. Its applicability is reduced to low saline $(<1 \%)$ and acid $(<5 \%)$ containing liquid samples using a general concentric nebulizer system. For this reason, in the case of the wet digestion method which is used in our laboratory practice (Kovács et. al., 1996), 5-fold dilution is required, whereby the overall dilution factor increases by 250 fold if one gram of solid sample was digested; our experience is that the concentration of arsenic and selenium decreases to $0,1-10 \mathrm{ng} \mathrm{cm}^{-3}$ level because of the attenuation (Table 1). In these cases, the sensitivity of ICP-MS is crucial.

Table 1

Arsenic and selenium content of triticale flour and plumseed

\begin{tabular}{|l|c|c|c|c|}
\hline & \multicolumn{2}{|c|}{ Arsenic concentration } & \multicolumn{2}{c|}{ Selenium concentration } \\
\hline Triticale flour & $\begin{array}{c}\text { Minimum } \\
(\mathrm{n}=49)\end{array}$ & $\begin{array}{c}\text { Maximum } \\
(\mathrm{n}=49)\end{array}$ & $\begin{array}{c}\text { Minimum } \\
(\mathrm{n}=49)\end{array}$ & $\begin{array}{c}\text { Maximum } \\
(\mathrm{n}=49)\end{array}$ \\
\hline $\begin{array}{l}\text { Measured concentration in the final } \\
\text { solution }\left[\mathrm{ng} \mathrm{cm}^{-3}\right]\end{array}$ & 0,486 & 5,86 & 0,121 & 1,11 \\
\hline Dilution factor & 249,9 & 250,0 & 249,9 & 250,0 \\
\hline Calculated element content $\left[\mathrm{ng} \mathrm{g}^{-1}\right]$ & 122 & 1460 & 30,1 & 278 \\
\hline Plumseed $)$ & $\begin{array}{c}\text { Minimum } \\
(\mathrm{n}=6)\end{array}$ & $\begin{array}{c}\text { Maximum } \\
(\mathrm{n}=6)\end{array}$ & $\begin{array}{c}\text { Minimum } \\
(\mathrm{n}=6)\end{array}$ & $\begin{array}{c}\text { Maximum } \\
(\mathrm{n}=6)\end{array}$ \\
\hline $\begin{array}{l}\text { Measured concentration in the final } \\
\text { solution [ng cm }\end{array}$ & 0,456 & 1,10 & 0,244 & 1,09 \\
\hline Dilution factor & 644,5 & 307,88 & 644,5 & 249,78 \\
\hline Calculated element content $\left[\mathrm{ng} \mathrm{g}^{-1}\right]$ & 294 & 340 & 157 & 272 \\
\hline
\end{tabular}

The sensitivity of the instrument can be optimized and improved by carefully setting its parameters:

- In the case of multi-element analysis, by setting the parameters to produce the highest net signal intensity on a solution containing analytes covering a wide mass range (Tune solution: $\mathrm{Li}, \mathrm{Be}, \mathrm{Co}$, $\mathrm{Ni}, \mathrm{In}, \mathrm{Ba}, \mathrm{Ce}, \mathrm{Pb}, \mathrm{U}$ ) and what must be done before any analysis; 
- In the case of mono-element analysis, by setting the parameters to produce the highest net signal intensity of the analyt,

- $\quad$ or as Montaser suggested (Montaser and Golighitly, 1987), by setting the parameters to produce the highest relative signal intensity.

For the latter, there is the need to devise an experiment to ascertain the relative signal intensities (which is a quotient: signal of arsenic and selenium solution / signal of blank).

The principle of ICP-MS is that the ions generated and sampled from the argon plasma (ICP) are detected by their charge/mass ratio (MS). This involves that the key of the ICP-MS method is the ion generation that is effective for ionization (Becker, 2007), which depends

- on the ionization potential of the element,

- on the quantity of aerosol fed to the plasma,

- on residence time in plasma of the atoms $(\sim \mathrm{ms})$,

- on the forward power coupled to the plasma.

Due to their high ionization potential, the ionization of arsenic and selenium is not complete (Záray, 2006).

The number of ionizable atoms increases proportionally with the aerosol quantity. This is influenced by the sample uptake rate and nebulazition effectiveness (which depends on nebulizer and auxiliarity gas flow rate).

The effectiveness of ionization increases with the residence time of atoms in the plasma (Todori and Mermet, 2008). The residence time depends on sampling depth (the distance between sample cone and the edge of torch), nebulizer gas flow rate and forward power. Furthermore, in addition to high forward power, the energy transmission between plasma and aerosol is greater (Nelms, 2008). Still, it must be considered that the processes taking place in the argon plasma (desolvation, sublimation, atomization and ionization) require energy too, thus cooling the plasma. Among the named processes, aerosol desolvation requires the most energy (McCurdy and Potter, 2001).

\section{MATERIALS AND METHODS}

My aim was to examine the effect of parameter value altering on signal intensity of arsenic and selenium and to reach the greatest relative signal intensity, thus lowering the detection limits.

The following parameters were examined:

- Auxiliary gas flow rate $\left(0,7 ; 0,9 ; 1,0 ; 1,1 ; 1,3 \mathrm{dm}^{3} \mathrm{~min}^{-1}\right)$

- $\quad$ Sampling depth $(0,10,20,30,40,50,100,200,400$ step)

- Forward power $(1200 \mathrm{~W}, 1400 \mathrm{~W}, 1600 \mathrm{~W})$

- $\quad$ Nebulizer gas flow rate $\left(0,72 ; 0,80 ; 0,84 ; 0,88 ; 0,92 \mathrm{dm}^{3} \mathrm{~min}^{-1}\right)$

- $\quad$ Sample uptake rate $\left(0,36 ; 0,47 ; 0,58 ; 0,71 ; 0,81 \mathrm{~cm}^{3} \mathrm{~min}^{-1}\right)$

The last three parameters were examined together.

The blank and solvent was $18 \mathrm{M} \Omega \mathrm{cm}$ inorganic purity $\left(25^{\circ} \mathrm{C}\right)$ (Millipore Corporation, USA, column: QuantumTM, EX Milli-Q) deionized water.

Arsenic and selenium signals $\left({ }^{75} \mathrm{As},{ }^{78} \mathrm{Se}\right.$ és $\left.{ }^{80} \mathrm{Se}\right)$ were measured with Thermo Elemental X7 inductively coupled plasma mass spectrometer using CCT (collision cell technology). The CCT gas consists of $7 \% \mathrm{H}_{2}$ and $93 \%$ He. For parameter optimization, a $500 \mu \mathrm{g} \mathrm{dm}^{-3}$ solution of As, Se and Mo was used.

\section{RESULTS AND DISCUSSION}

\subsection{Effect of auxiliary gas flow rate}

Arsenic

For the blank a $15 \%$ decrease, and for the sample a $35 \%$ increase of signal intensity was observed as the auxiliary gas flow rate changed from 0,7 to $1,3 \mathrm{dm}^{3} \mathrm{~min}^{-1}$. The relative signal intensity improved with $60 \%$ (Figure 1.)

Selenium

Unlike arsenic, the relative signal intensity of selenium gave maximum at $1,0 \mathrm{dm}^{3} \mathrm{~min}^{-1}$ flow rate for both isotopes (Figure 1.). For the blank a $30 \%$, for the sample a $60 \%$ of improvement in net signal intensity could be reached at maximum. 
Figure 1: Effect of auxiliary gas flow rate on relative signal intensity

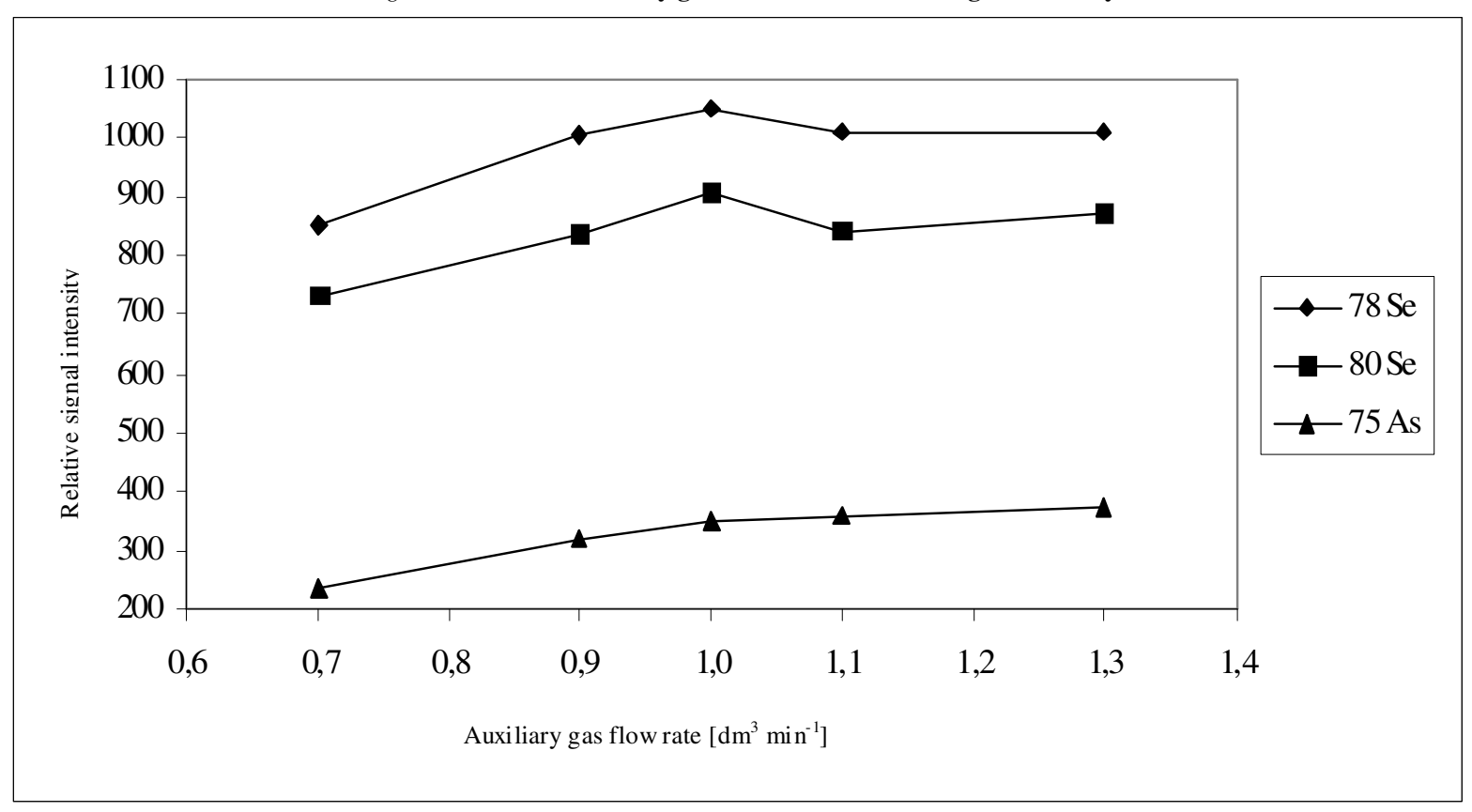

\subsection{Effect of sampling depth}

By altering the sampling depth the ion sampling is originated from distinct temperature zones of the plasma, but by taking away the torch from sampling cone the amount of ions reaching the analyzer chamber is reduced (Montaser, 1998).

As the plasma was taking away from the sampling cone, both the intensities of the sample and the blank decreased. In the case of the sample solution, the intensity at value 10 was higher than the others nearby. This could be because the ionisation rate was better in that plasma segment. The relative signal intensity reached the maximum at sampling depth value 100 , which in contrast to 0 was a $28 \%$ for arsenic, $48 \%$ for ${ }^{78}$ Se and $30 \%$ for ${ }^{80}$ Se increase. (Figure 2).

Figure 2: Effect of sampling depth on relative signal intensity

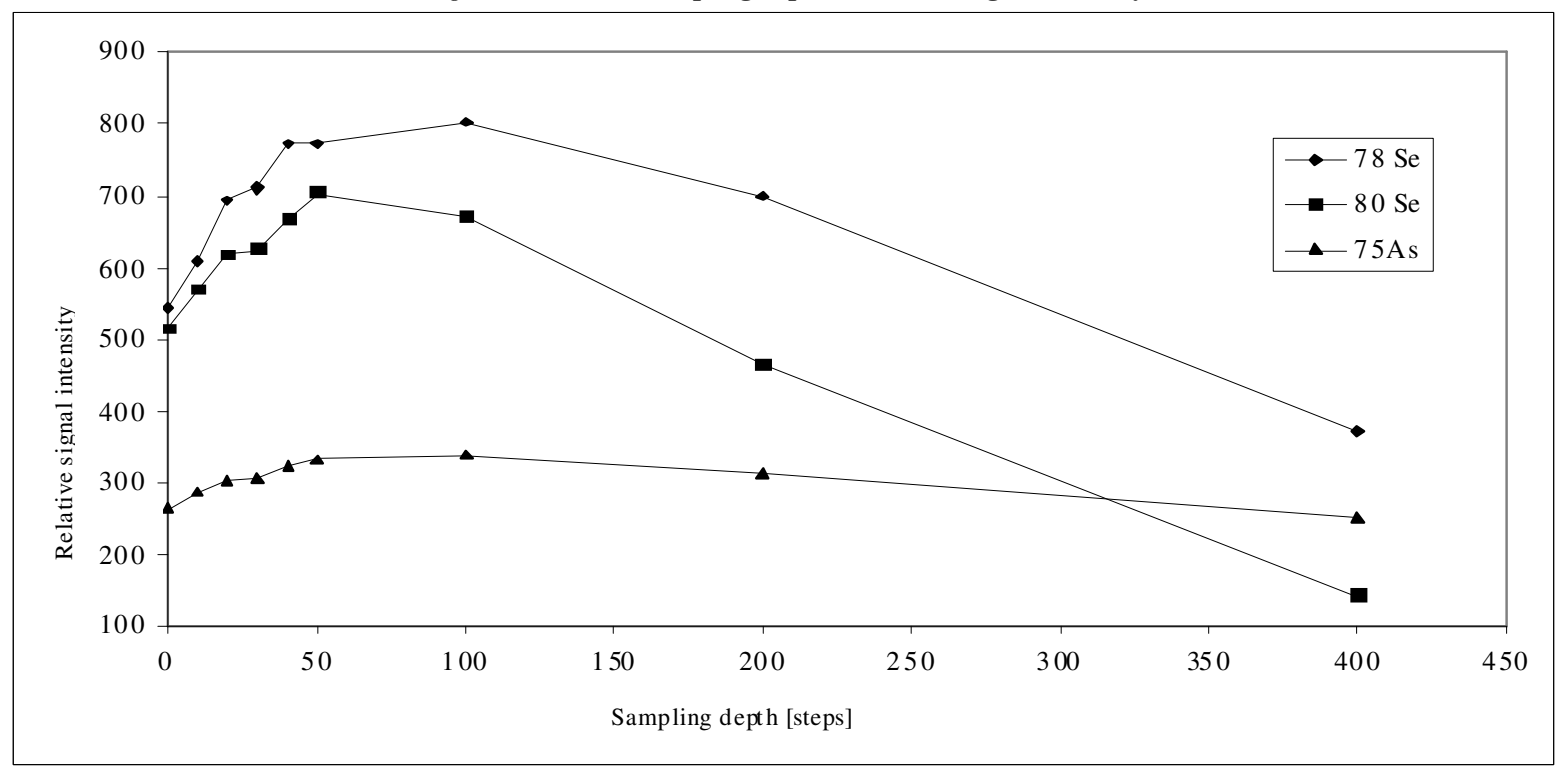

\subsection{Effect of nebuliser gas flow rate, sample uptake rate and forward power}

These parameters were examined together. Increasing the amount of aerosol fed to the plasma and by this method, the analytic quantity enhances the analytical sign, and better aerosol generation is attainable through optimal nebuliser gas flow. However, the higher amount of aerosol also cools the plasma, and confines ionization effectiveness. The greater relative sign intensities was attained at the highest sample uptake rate 
examined $\left(0,81 \mathrm{~cm}^{3} \mathrm{~min}^{-1}\right)$; however, considering the forward power and nebuliser gas flow rate, they differ. (Table 2).

Parameter settings resulting maximal relative signal intensities

\begin{tabular}{|c|c|c|c|}
\hline Element & $\begin{array}{c}\text { Relative signal } \\
\text { intensity } \\
\text { maximum }\end{array}$ & $\begin{array}{c}\text { Forward } \\
\text { power } \\
{[\mathrm{W}]}\end{array}$ & $\begin{array}{c}\text { Nebuliser } \\
\text { gas flow } \\
\text { rate } \\
{\left[\mathrm{dm}^{3} \mathrm{~min}^{-1}\right]}\end{array}$ \\
\hline${ }^{75} \mathrm{As}$ & 1000 & 1200 & 0,84 \\
\hline${ }^{78} \mathrm{Se}$ & 3500 & 1200 & 0,84 \\
\hline${ }^{80} \mathrm{Se}$ & 1050 & 1600 & 0,88 \\
\hline
\end{tabular}

\subsection{Determination of detection limits}

The detection limits were determined both with parameter settings of maximal relative signal intensities and of maximal net intensities received by the tune solution (Table 3.), and were calculated by the formula LOD $=3$ $\sigma / \mathrm{R}$ whereas $\sigma$ is the standard deviation of blank, $\mathrm{R}$ is the analytical sensitivity.

Table 3

Parameters applied for detection limit determination

\begin{tabular}{|c|c|c|c|c|c|}
\hline \multicolumn{6}{|c|}{ Parameter settings resulting nett signal intensity maximum on tune solution } \\
\hline Element & $\begin{array}{c}\text { Auxiliary gas } \\
\text { flow rate } \\
{\left[\mathrm{dm}^{3} \mathrm{~min}^{-1}\right]} \\
\end{array}$ & $\begin{array}{l}\text { Sampling depth } \\
\text { [number of steps] }\end{array}$ & $\begin{array}{l}\text { Sample uptake rate } \\
\qquad\left[\mathrm{cm}^{3} \mathrm{~min}^{-1}\right]\end{array}$ & $\begin{array}{l}\text { RF power } \\
{[\mathrm{W}]}\end{array}$ & $\begin{array}{c}\text { Nebuliser gas } \\
\text { flow rate } \\
{\left[\mathrm{dm}^{3} \mathrm{~min}^{-1}\right]} \\
\end{array}$ \\
\hline $\begin{array}{l}\mathrm{Li}, \mathrm{Be}, \\
\mathrm{Co}, \mathrm{Ni}, \mathrm{In}, \\
\mathrm{Ba}, \mathrm{Ce}, \\
\mathrm{Pb}, \mathrm{U}\end{array}$ & 1,15 & 15 & 0,81 & 1400 & 0,85 \\
\hline \multicolumn{6}{|c|}{ Parameter settings resulting relative sign intensity maximum } \\
\hline Element & $\begin{array}{l}\text { Auxiliary gas } \\
\text { flow rate } \\
{\left[\mathrm{dm}^{3} \mathrm{~min}^{-1}\right]}\end{array}$ & $\begin{array}{l}\text { Sampling depth } \\
\text { [number of steps] }\end{array}$ & $\begin{array}{l}\text { Sample uptake rate } \\
\qquad\left[\mathrm{cm}^{3} \mathrm{~min}^{-1}\right]\end{array}$ & $\begin{array}{c}\text { RF power } \\
{[\mathrm{W}]}\end{array}$ & $\begin{array}{c}\text { Nebuliser gas } \\
\text { flow rate } \\
{\left[\mathrm{dm}^{3} \mathrm{~min}^{-1}\right]} \\
\end{array}$ \\
\hline As & 1,30 & 100 & 0,81 & 1200 & 0,84 \\
\hline $\mathrm{Se}$ & 1,00 & 50 & 0,81 & 1600 & 0,88 \\
\hline
\end{tabular}

The achieved detection limits are summarized in Table 4.; for selenium, only isotope 80 is represented, because it is the most abundant isotope.

Table 4

Detection limits

\begin{tabular}{|c|c|c|c|}
\hline \multicolumn{4}{|c|}{ With parameter settings resulting nett signal intensity maximum } \\
\hline \multirow{2}{*}{ Element } & $\begin{array}{c}\text { Standard } \\
\text { deviation of } \\
\text { blank } \sigma(\mathrm{n}=11)\end{array}$ & $\begin{array}{c}\text { Analitical } \\
\text { sensitivity }\end{array}$ & $\begin{array}{c}\text { Limit of detection } \\
{\left[\mathrm{ng} \mathrm{cm}^{-3}\right]}\end{array}$ \\
\hline As & 36,44 & 2617 & 0,041 \\
\hline Se & 74,15 & 1950 & 0,114 \\
\hline \multicolumn{2}{|c|}{ With parameter settings resulting relative signal intensity maximum } \\
\hline Element & $\begin{array}{c}\text { Standard } \\
\text { deviation of } \\
\text { blank } \sigma(\mathrm{n}=11)\end{array}$ & $\begin{array}{c}\text { Analitical } \\
\text { sensitivity }\end{array}$ & $\begin{array}{c}\text { Limit of detection } \\
{\left[\mathrm{ng} \mathrm{cm}^{-3}\right]}\end{array}$ \\
\hline As & 20,26 & 1915 & 0,032 \\
\hline Se & 38,35 & 1185 & 0,097 \\
\hline
\end{tabular}

In conclusion, although the analytical sensitivity is also decreased, in addition to the deviation of the blank, it was successful to attain a lower detection limit for both elements. 


\section{SUMMARY}

Our knowledge is broadened about the role and mechanism of arsenic and selenium in organisms. Because of their effect, which can be either beneficial or toxic, depends on the level in which they occur, it is important to know their concentrations in drinking water and foodstuffs. For this purpose, the best applicable method is ICP-MS, but by the wet digestion method applied in laboratory practice, the concentration of arsenic and selenium in the final solution may decrease as low as the detection limit. In these cases, the sensitivity of the ICP-MS instrument is crucial.

In our work, we have compared two sensitivity enhance strategies:

- a parameter optimization, which must be done before any analyses on a multielemental solution - it is called tune

- a parameter optimization, aims to attain the relative signal maximum for the two analyt.

The detection limits with the latter strategy were given lower both of arsenic and selenium.

\section{REFERENCES}

J. S. Backer (2007): Inorganic mass spectrometry: principles and applications. Wiley-Interscience. ISBN 9780470012000

Kovács B.-Győri Z.-Prokisch J.-Loch J.-Dániel P. (1996): A study of plant sample preparation and inductively coupled plasma emission spectometry parameters. Communications in Soil Science and Plant Analysis. 27(5-8), 1177-1198.

E. McCurdy-D. Potter (2001): Optimising ICP-MS for the determination of trace metals in high matrix samples. Spectroscopy Europe 13/3

A. Montaser (1998): Inductively coupled plasma mass spectrometry. Wiley-WHC, ISBN 9780471186205

A. Montaser-D.W.Golighitly (1987): Inductively coupled plasmas in analytical atomic spectrometry. VCH Publishers. New York.

S. Nelms (2008): Inductively coupled plasma mass spectrometry handbook. Wiley-Blackwell, ISBN 9781405109764

J. L. Todori-J. M. Mermet (2008): Liquid sample intriduction in ICP spectrometry: a practical guide. Elsevier, ISBN 978-0-444-53142-1

Záray Gy. (2006): Az elemanalitika korszerü módszerei. Akadémiai Kiadó, Budapest 